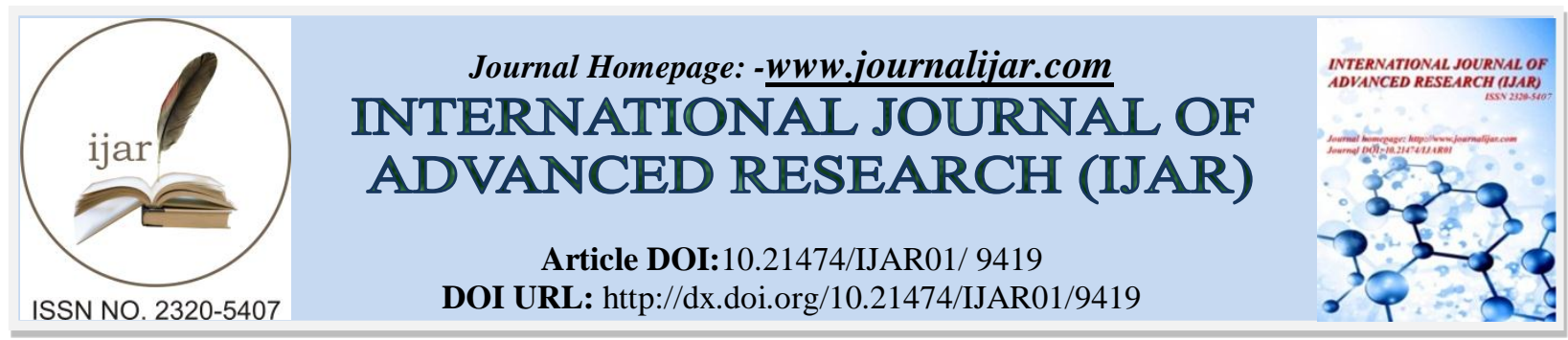

RESEARCH ARTICLE

\title{
MICROBIOLOGICAL INVESTIGATION OF WATER QUALITY OF TWO CENTURY OLD LAKES, FROM JHANSI, BUNDELKHAND REGION.
}

\author{
Divya Saxena ${ }^{1}$, Dr. Deepak sahay Saxena ${ }^{2}$ and Dr. Amit Pal ${ }^{3}$. \\ 1. Research Scholar,(Dept.of Environmental Sciences),Bundelkhand University, Jhansi. \\ 2. M.V.Sc.,Veterinary Doctor,Vidisha (M.P.). \\ 3. Professor(Environmental Sciences), Bundelkhand University, Jhansi.
}

\section{Manuscript Info}

Manuscript History

Received: 22 May 2019

Final Accepted: 24 June 2019

Published: July 2019

Key words:-

Century old lake, Water samples, Bacteriological analysis, BOD,COD, E.coli, Steptococcus, Citrobacter, Vibrio sps.
.........................

\begin{abstract}
The microorganisms present in water cause harmful effects in human body. Supply of drinking water contaminated with sewage or other excreted matter from men and animals may cause intestinal infections, dysentery, hepatitis, typhoid fever, cholera, and other illnesses. The paper discusses results of microbiological analysis done on various water samples taken from two different century old lakes of Jhansi, Bundelkhand Region. This study carried out in the month of AprilJune (2013) for which two lakes were chosen i.e. Barua Sagar Lake, Antiya Tal Lake etc. The samples were first collected and then stored in water storages made up of different materials like earthen material, plastic container. The sample temperatures ranged from $17.5-23^{\circ} \mathrm{C}$, $\mathrm{pH}$ from $7.32-7.6$, turbidity from 22.8-35 NTU, DO from $6.3-10$ $\mathrm{mg} / \mathrm{l}$, BOD from $2.4-4.25 \mathrm{mg} / \mathrm{l}$, COD ranged from $40.2-55.8 \mathrm{mg} / \mathrm{L}$, total alkalinity from 32-118 mg/l and total hardness from $220.5-22.5$ $\mathrm{mg} / \mathrm{L}$. All samples were positive for E. coli, Pseudomonas, Staphylococcus, Citrobacter, Bacillus sps .which indicates fecal pollution of water. The results indicated that microbiological parameters of the water were effected by the anthropogenic activities and can be used for domestic, irrigation, agriculture and pisciculture after proper management.
\end{abstract}

Copy Right, IJAR, 2019,. All rights reserved.

\section{Introduction:-}

Water being a universal solvent has been and is being utilized by mankind time and now. The human body has $55 \%$ to $78 \%$ water depending on body size. Since, water is one of the essential components required to our body, it is important to assess the quality of water, which is being used for household activities as well as consumption whether it is actually reliable and safe for health of the consumers. Water potability refers to the quality of water that can be safe for consumption and use with no risk of adverse health effects. With the rapid development in agriculture, mining, urbanization, and industrialization activities, the river water contamination with hazardous waste and wastewater is becoming a common phenomenon. The water quality and human health are closely related. The domestic waste from each building along with the effluent of small scale industries is disposed off into the open drains and gutters which ultimately enter into the rivers. Lakes are the important source of fresh water in Bundelkhand Region. Lakes are stagnant surface water bodies, receive and stores rain fall water. Stagnant water 
bodies have more complex and fragile ecosystem and hence readily accumulate great quantities of pollutants. Increased anthropogenic activities in and around the water bodies damage the aquatic ecosystems and ultimately the physico chemical properties of water (Upadhyay et al., 2010). Drinking contaminated water can cause diarrhoea, cholera, dysentery, and various other diseases like Typhoid, Amoebiasis, Jaundice, Enterobacteriaceae, etc. The increased demand of water as a consequence of population growth, agriculture and industrial development has forced environmentalist to determine the chemical, physical and biological characteristics of natural water resources (Regina and Nabi, 2003). The present study was under taken to define the various point sources of pollutants in the two century old lakes and to assess the quality of water samples with special reference to microbiological properties in various months and stations.

\section{Materials and Methods:- \\ Study Area}

Jhansi is well known district of Bundelkhand region of Uttar Pradesh with a geographical area of 502.75 thousand hectare. The district is situated in the South West corner of the region at $24^{\circ} 11^{\prime}-25^{\circ} 57^{\prime} \mathrm{N}$ latitude and $78^{\circ} 10^{\prime}-79^{\circ}$ 23' E longitudes. The average rainfall is $800-900 \mathrm{~mm} /$ year. Population of Jhansi is near about 4, 79,612. The western area of the district is covered with hillocks. Land is suitable for citrus species fruits. Crops include wheat, pulses, peas, oilseeds. Surface water is the main source of water in Jhansi. Betwa river, Pahuj river, Barua Sagar Lake ,Lakshmi Tal, Antiya Tal are the main source of water. After treatment, the surface water is supplied to various areas through pipelines for municipal uses. Antiya lake is located between latitude $25012^{\prime}$ N-120 16' and longitude 780 18' E- 780 23' E in Jhansi City, Bundelkhand region, Central India. Barua Sagar is a historical place located about $25 \mathrm{~km}$ from Jhansi in Uttar Pradesh, India. It is situated on the bank of the Betwa River, the place is named after the Barua Sagar Taal, a large lake created about 260 years ago when Raja Udit Singh of Orchha built the embankment. Area is 4.64 sq. Km; altitude is $210 \mathrm{mtrs}$ above MSL. Monthly water sample have been collected from 5 different point of the two lakes as fallow: Site1- East; Site 2- South; Site 3- West; Site 4- North; Site-5 Centre respectively.

\section{Analytical design}

Water samples were collected from the lake, $10-15 \mathrm{~cm}$ below the surface during winter (April to June). The sampling locations were choosen carefully in order to get maximum representation of the diverse eco hydrological environments within the lake system. Sample containing bottles were placed in insulated wooden or plastic boxes and transported to the laboratory. Samples were stored at $4{ }^{\circ} \mathrm{C}$ for further use. Bacteriological analysis was done using HiSelective $\mathrm{H}_{2} \mathrm{~S}$ Medium for detection of Salmonella, Staphylococcus ,Streptococcus, Bacillus, Citrobacter, Pseudomonas, E.coli sps. In this Vials were filled with water sample upto arrow level and then the vials were swirl carefully to completely dissolve the powder. The vials were then incubated at $32-35^{\circ} \mathrm{C}$ for $24-48$ hrs and then the result was observed. The various morphological characteristics of recovered isolates viz., colony morphological (Colour, Shape, Arrangement and Gram staining) and the biochemical tests carried out for identification of isolates (Holt et al. 1994).

\section{Result and Discussion:-}

Bacteriological analysis showed the four microbes in lake water samples. All samples had E. coli, as indicator of fecal pollution. Staphylococcus aureus was found in five samples of Barua sagar lake. Bacillus cereus was present in four samples of Antiya Lake and Pseudomonas spp was found in three samples of both the lakes. E. coli cause urinary tract infection and diarrhea and. Pseudomonas species can cause disease in animals and humans (Balcht 1994). Pseudomonas can, in rare circumstances, cause community-acquired pneumonias as well as ventilatorassociated pneumonias, being one of the most common agents isolated in several studies (Fine et al. 1996). Staphylococcus species is the most common cause of staph infections. It can cause a range of illnesses from minor skin infections, such as pimples, impetigo, boils, cellulitis folliculitis, furuncles, carbuncles, scalded skin syndrome and abscesses, to life-threatening diseases such as pneumonia, meningitis, osteomyelitis, endocarditis, toxic shock syndrome, and septicemia.

Simultaneous Detection of Microbes in Water Samples By Colour Change In Hi Selective Medium:

\begin{tabular}{|c|c|}
\hline Colour obtained & Microorganism might present \\
\hline Black with turbidity & Citrobacter species, Salmonella species \\
\hline bluish green with turbidity & $\begin{array}{c}\text { Escherichia coli, Shigella species, Streptococcus species, } \\
\text { Pseudomonas species }\end{array}$ \\
\hline
\end{tabular}




\begin{tabular}{|c|c|}
\hline bluish green with turbidity & $\begin{array}{c}\text { Escherichia coli, Staphylococcus species, Pseudomonas } \\
\text { species }\end{array}$ \\
\hline bluish green without turbidity & Bacillus sps, Salmonella sps, Vibrio sps \\
\hline
\end{tabular}
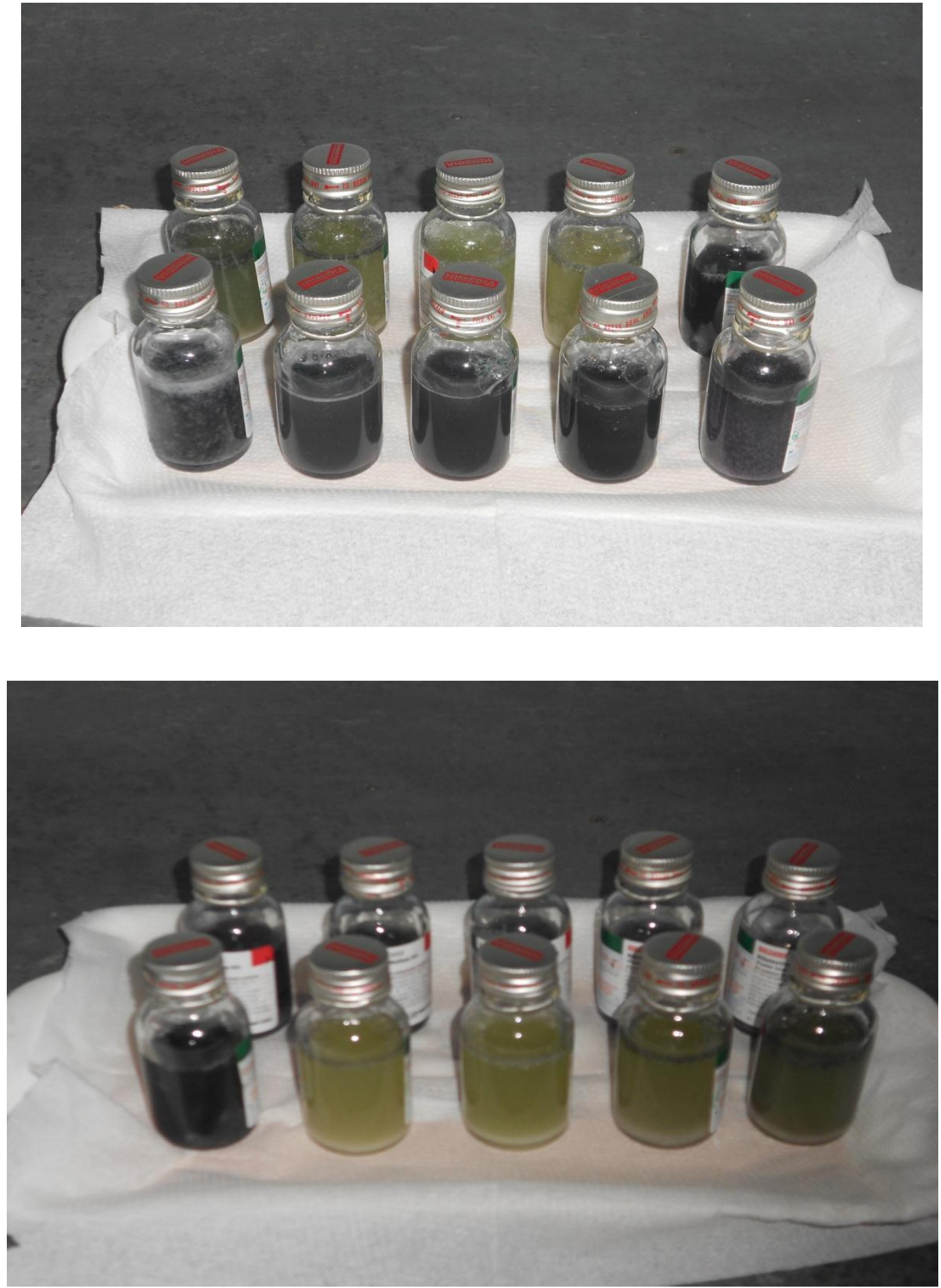
Table 1:-Microbiological analysis of water sample of Barua Sagar Lake:

\begin{tabular}{|l|l|l|l|l|l|}
\hline Microorganisms & \multicolumn{1}{c|}{$\begin{array}{c}\text { Site 1 } \\
\text { sample }\end{array}$} & $\begin{array}{c}\text { Site 2 } \\
\text { sample }\end{array}$ & $\begin{array}{c}\text { Site 3 } \\
\text { sample }\end{array}$ & $\begin{array}{c}\text { Site 4 } \\
\text { sample }\end{array}$ & $\begin{array}{c}\text { Site 5 } \\
\text { sample }\end{array}$ \\
\hline E.coli sps & + & + & + & + & + \\
\hline Streptococcus sps & \multicolumn{1}{|c|}{} & - & - & + & + \\
\hline Staphyloccus sps & + & + & + & + & + \\
\hline Bacillus sps & - & - & - & - & - \\
\hline Pseudomonas sps & - & + & + & - & + \\
\hline Citrobacter sps & - & - & - & - & - \\
\hline
\end{tabular}

Table 2:-Microbiological analysis of water sample of Antiya Lake:

\begin{tabular}{|l|l|l|l|l|l|}
\hline Microorganisms & Site 1 sample & $\begin{array}{l}\text { Site 2 } \\
\text { Sample }\end{array}$ & Site3 sample & Site 4 sample & Site 5 sample \\
\hline E.coli sps & + & + & + & + & + \\
\hline Streptococcus sps & - & - & - & - & - \\
\hline Staphyloccus sps & - & - & - & - & - \\
\hline Bacillus sps & + & + & - & + & + \\
\hline Pseudomonas sps & + & - & + & + & - \\
\hline Citrobacter sps & - & - & - & - & - \\
\hline
\end{tabular}

Fig 1:-Microscopic View of Various Bacterial IsolatesBacillus bacterial sps.

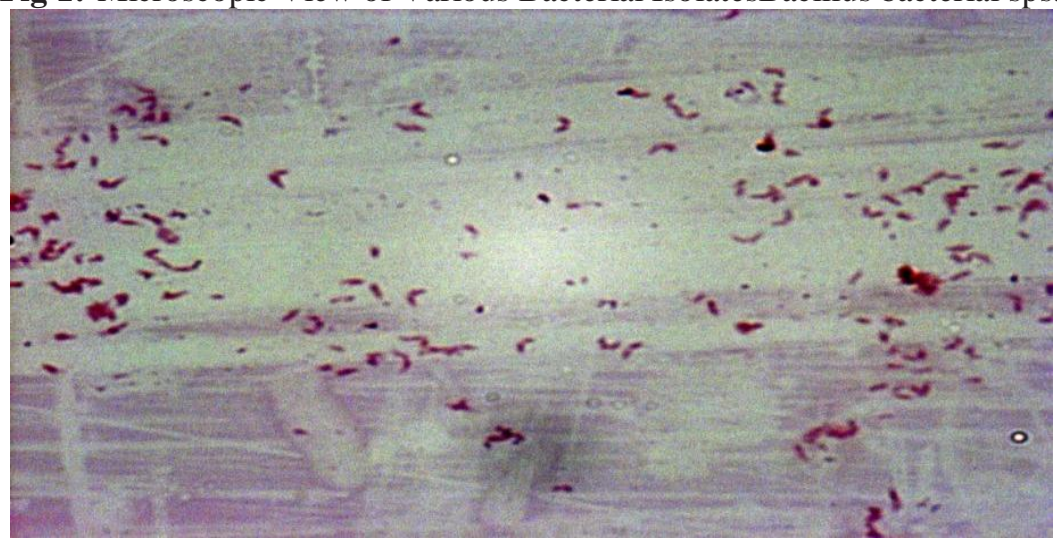

Fig 2:-Staphylococcus sps.

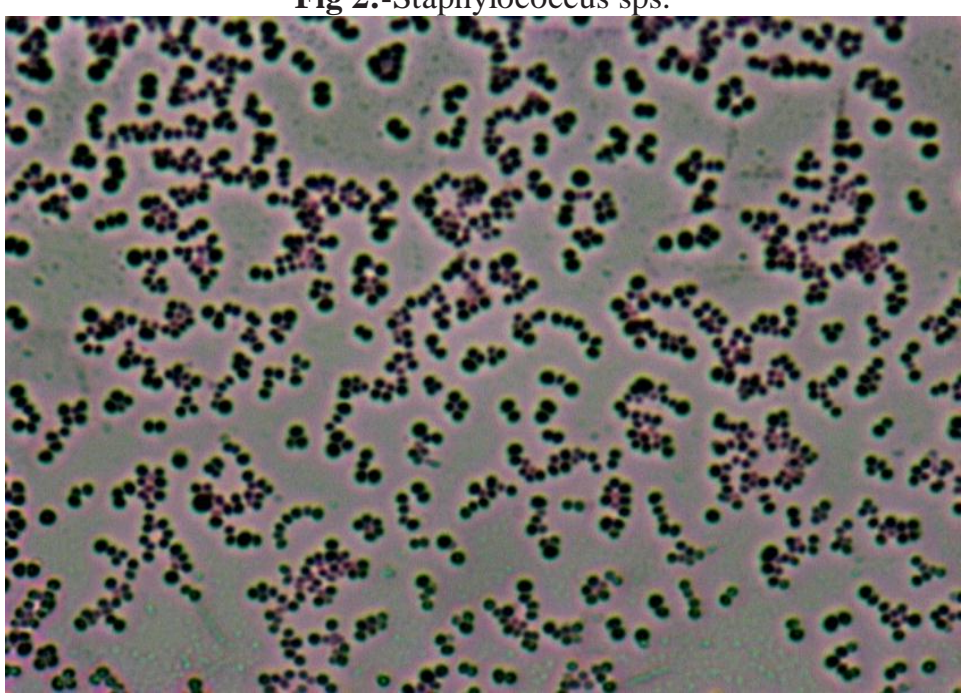



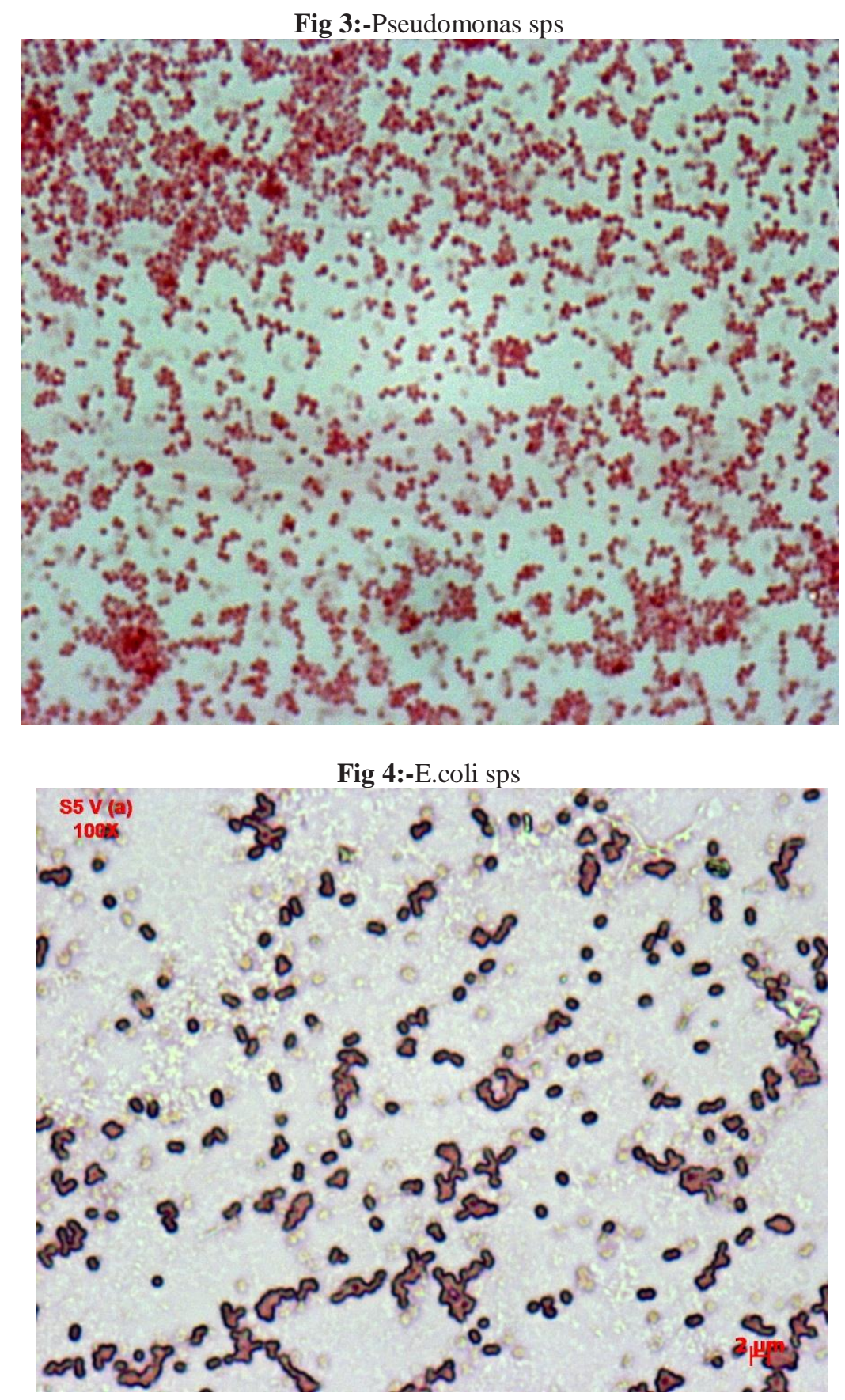

\section{Conclusion:-}

The present investigations conclude that the quality of water samples subjected to study was acceptable from physico-chemical parameters, while presence of various bacterial isolates shows that the water of both the lakes may not be suitable for drinking. If the similar condition continue for longer period, lake may soon become ecological inactive. So, it should be the prime responsibility of Jhansi Municipal Corporation to monitor the water quality of lake continuously, and should take important steps along with the government and various NGO's so that the water quality of the lake should be maintained efficiently.

\section{Acknowledgement:-}

Authors are grateful to Dr. Amit Pal, Dr.Vinit Kumar for their valuable suggestions and technical help. 


\section{References:-}

1. APHA. Standard methods for the examination of water and waste water. 19th Edition, American Public Health Association, American Water Work Association and Water Pollut. Contl. Federation, Washington, D.C.,NewYork, (1995).

2. Balcht Aldona 1994. Pseudomonas aeruginosa: Infections and Treatment. Informa Health Care, 21: 83-84.

3. Fine MJ, Smith MA, Carson CA 1996. Prognosis and outcomes of patients with community-acquired pneumonia. A meta-analysis. JAMA, 275(2): 134-141.

4. Holt JG, Krieg NR, Senath PHA, Staley JT, Williams ST 1994. Bergey's Manual of Determinative Bacteriology. 9thEdition. Baltimore Md.: Willaims and Wilkins.

5. Kumar Ashok, Bisht BS, Talwar Amitabh, Chandel Deepika 2010. Physico-Chemical and Microbial Analysis of Ground Water from Different Regions of Doon Valley. Int Jou Appl Env Sci, 5(3): 433-440.

6. Regina, B and Nabi, B(2003). Physiochemical spectrum of the Bhavani river water collected from the Kalingaryan dam, Tamilnadu. Indian Journal of Environment and ecoplanning., 7(3), 633-636.

7. Upadhyay K, Mishra P and Gupta AK (2010) Studies on the physico-chemical status of two ponds at Varanasi and Bhadohi under biotic stress, Plant Archives 10(2) 691-693.

8. WHO (1971), International Standards for drinking water, $3^{\text {rd }}$ Ed. Geneva, World Health Organization.

9. WHO (World Health Organization), 1993. Guidelines for drinking-water quality, vol. 1, Recommendations, Geneva, WHO, 130.

10. WHO 1999. Guidelines for Drinking Water Quality. $2^{\text {nd }}$ Edition. Geneva: WHO. 